\title{
Study of the Physico-Chemical and Bacteriological Characteristics of Drinking Water in So-Ava, South Benin
}

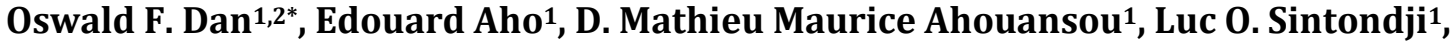 \\ Laetitia Assoti $^{3}$, Josué Zandagba ${ }^{4}$, Dodji Amouzouvi²
}

${ }^{1}$ Laboratory of Hydraulics and Water Control, National Institute of Water, University of Abomey-Calavi (LHME/INE/UAC), Abomey-Calavi, Benin

${ }^{2}$ Laboratory of Analysis and Research, Religions, Space and Development, (LARRED/FLAC/UAC), Abomey-Calavi, Benin

${ }^{3}$ National Polytechnic Institute-Felix Houphouet Boigny (INP-HB), Yamoussoukro, Côte d'Ivoire

${ }^{4}$ Laboratory of Applied Hydrology, National Institute of Water, University of Abomey-Calavi (LHA/INE/UAC),

Abomey-Calavi, Benin

Email: *oswalddan01@gmail.com

How to cite this paper: Dan, O.F., Aho, E., Ahouansou, D.M.M., Sintondji, L.O., Assoti, L., Zandagba, J. and Amouzouvi, D. (2018) Study of the Physico-Chemical and Bacteriological Characteristics of Drinking Water in So-Ava, South Benin. Journal of Water Resource and Protection, 10, 1031-1046.

https://doi.org/10.4236/jwarp.2018.1011060

Received: September 26, 2018

Accepted: October 28, 2018

Published: October 31, 2018

Copyright (C) 2018 by authors and Scientific Research Publishing Inc. This work is licensed under the Creative Commons Attribution International License (CC BY 4.0).

http://creativecommons.org/licenses/by/4.0/ cc) (†) Open Access

\begin{abstract}
The present study assesses the physicochemical and bacteriological quality of the drinking water used by the population of Sô-Ava based on the Beninese standards and those established by the World Health Organization (WHO). In rural and peri-urban areas of Benin where public water supply systems are inadequate or almost non-existent, the population consumes water of various sources of unknown qualities. A total of 67 water samples were analyzed during the rainy season (July 2017) and in the dry season (January 2018) for certain physical, chemical and bacteriological parameters using the standard methods. The results of the analyses reveal that the physicochemical characteristics of the water used for consumption in Sô-Ava comply with the drinking water standards of the World Health Organization and those in force in Benin except for the percentages of the following parameters: $\mathrm{pH}(41.80 \%)$; turbidity (25.37\%); the color (16.42); ammonium (17.91\%); iron $(40.30 \%)$; Nitrites (4.48\%); Residual chlorine (91.05). Bacteriologically, the analyses showed a high total aerobic mesophilic flora contamination, faecal coliforms, E. coli, faecal enterococci respectively in $89.55 \%, 82.09 \%, 50.75 \%$ and $70.15 \%$ of the analyzed water samples. The ratio of faecal coliforms to faecal enterococci indicated that the origin of faecal contamination was human in $59.7 \%$ of the samples and animal in $40.3 \%$ of the samples. The adoption of hygiene measures at the water point, during the transport and storage of water, including the treatment by chlorination of drinking water at the family level was recommended for the population concerned and household awareness on the
\end{abstract}


adoption of basic hygiene and sanitation measures have been recommended for hygiene and sanitation services.

\section{Keywords}

Drinking Water, Quality, Bacteriology, Pollution, Sô-Ava, Benin

\section{Introduction}

Water is an indispensable element for the lives of humans, animals and plants. Having sufficient water in quantity and quality contributes to the maintenance of health [1]. Access to safe drinking water is a prerequisite for health, a basic human right and a key component of effective health protection policies [2]. As such, the joint WHO/UNICEF monitoring program for water supply and sanitation (JMP) indicates that significant progress has been made over the last two decades with 2.6 billion people accessing improved source of drinking water and 2.1 billion to an improved hygiene service. However, efforts remain to be made as 663 million people remain without an improved source of drinking water with 319 million in sub-Saharan Africa, and 2.4 billion without an improved sanitation facility and among those who still do not have access to the water points, 8 out of 10 live in rural areas [3].

The water supply systems are considered a water service heritage for which good management is necessary to ensure their survival and smooth operation [4]. However, the quality of the water may change during its transfer from the outlet of the treatment plant to the consumer's tap. The substances it carries are likely to be ingested, inhaled, or come in contact with the skin. The problem of drinking water supply is a key issue for African countries in general and those in West Africa in particular [5].

In Benin, the problem of access to good water quality is still present in rural and peri-urban areas. Indeed, in the lakeside community of Sô-Ava, which is our study area, rainwater, lake, boreholes and water of the National Water Company of Benin (SONEB) represent the various sources of water used by the population. The rate of drinking water coverage in the whole commune is close to $49.43 \%$ [6]. The populations are thus confronted to: the consumption of sometimes unimproved water sources, recurrent water shortages, long distances to go to the water point, .... However, contaminated and unhealthy water is a potent factor in the transmission of waterborne diseases [7]. Thus the consumption of water of doubtful quality can lead to the appearance of waterborne diseases such as cholera, diarrhea, typhoid fever, gastrointestinal infections, etc. [8]. The risks associated with the contamination of drinking water are many and may depend not only on the lack or inadequacy of hygiene measures at the source of supply but also during transport, from the storage of water to drinking water home. Therefore, to determine the relevance of the problems related to access to drinking water, this study aims to assess the hygienic quality of water used for 
drinking by the population of the municipality of Sô-Ava by physicochemical and bacteriological analyses.

\section{Material and Methods}

\subsection{Presentation of the Study Area}

The study was conducted in the lake district of Sô-Ava, located in the Atlantic Department. The commune of Sô-Ava occupies the lower valley of the Ouémé River and the Sô River to which it owes its name (Figure 1). With an area of 218 sq. $\mathrm{Km}$ [9] it has 118,547 inhabitants with a density of about 567 inhabitants per sq. $\mathrm{Km}[10]$.

The municipality of Sô-Ava enjoys a humid tropical climate, characterized by the alternation of two rainy seasons and two dry seasons. The big rainy season runs from March to July and the small one from September to November. The average annual rainfall is $1200 \mathrm{~mm}$. Temperatures range from a low of $22^{\circ} \mathrm{C}$ to a high of $33^{\circ} \mathrm{C}$.

Hydrologically, the municipality of Sô-Ava is characterized by the wealth of its water bodies ( $65 \%$ of the town), hence its name of common lacustrine. Its main river is the Sô River which flows into Lake Nokoué (a lagoon in fact) [11].

Administratively, the commune of Sô-Ava is subdivided into seven (07) arrondissements namely: Sô-Ava, Vekky, Houédo-Aguékon, Dékanmè, Ganvié 1, Ganvié 2 and Ahomey-lokpo [6].

\subsection{Sampling and Evaluation of Physico-Chemical Parameters}

\subsubsection{Sampling Methods and Analyses}

A total of 67 water samples distributed over all 7 arrondissements were collected and analyzed during the rainy season (July 2017) and then in the dry season (January 2018) according to the methods described by [12]. The sampling points are marked in red in Figure 1. The plastic bottles are washed beforehand and rinsed three (03) times with water before being used for taking any sample. The water samples were collected into appropriate plastic bottles of mineral water with a capacity of 1.5 liters for physico-chemistry and $210 \mathrm{ml}$ Whirl-Pak sachets for microbiology. The latter have been labeled and placed in a cooler with cold accumulators at a temperature between $0^{\circ} \mathrm{C}$ and $4^{\circ} \mathrm{C}$. They were then sent to the Laboratory of Quality Control of Water and Food (LCQEA) of the Ministry of Health accompanied by a specimen sheet containing all the necessary information including the origin and date of sampling and sanitary conditions from the sampling point.

\section{Physicochemical analyses}

The physicochemical parameters were monitored according to the techniques of [12]. Temperature, hydrogen potential $(\mathrm{pH})$, electrical conductivity (EC) and total dissolved solids (TDS) were measured in situ by the portable multi-parametric analyzer. Nitrates $\left(\mathrm{NO}^{3-}\right)$, nitrites $\left(\mathrm{NO}^{2-}\right)$, ammoniacal nitrogen $\left(\mathrm{NH}_{4}^{+}\right)$, sulphates $\left(\mathrm{SO}_{4}^{2-}\right)$, ortho-phosphate $\left(\mathrm{PO}_{4}^{3-}\right)$, iron $(\mathrm{Fe})$, fluorides $\left(\mathrm{F}^{-}\right)$ 


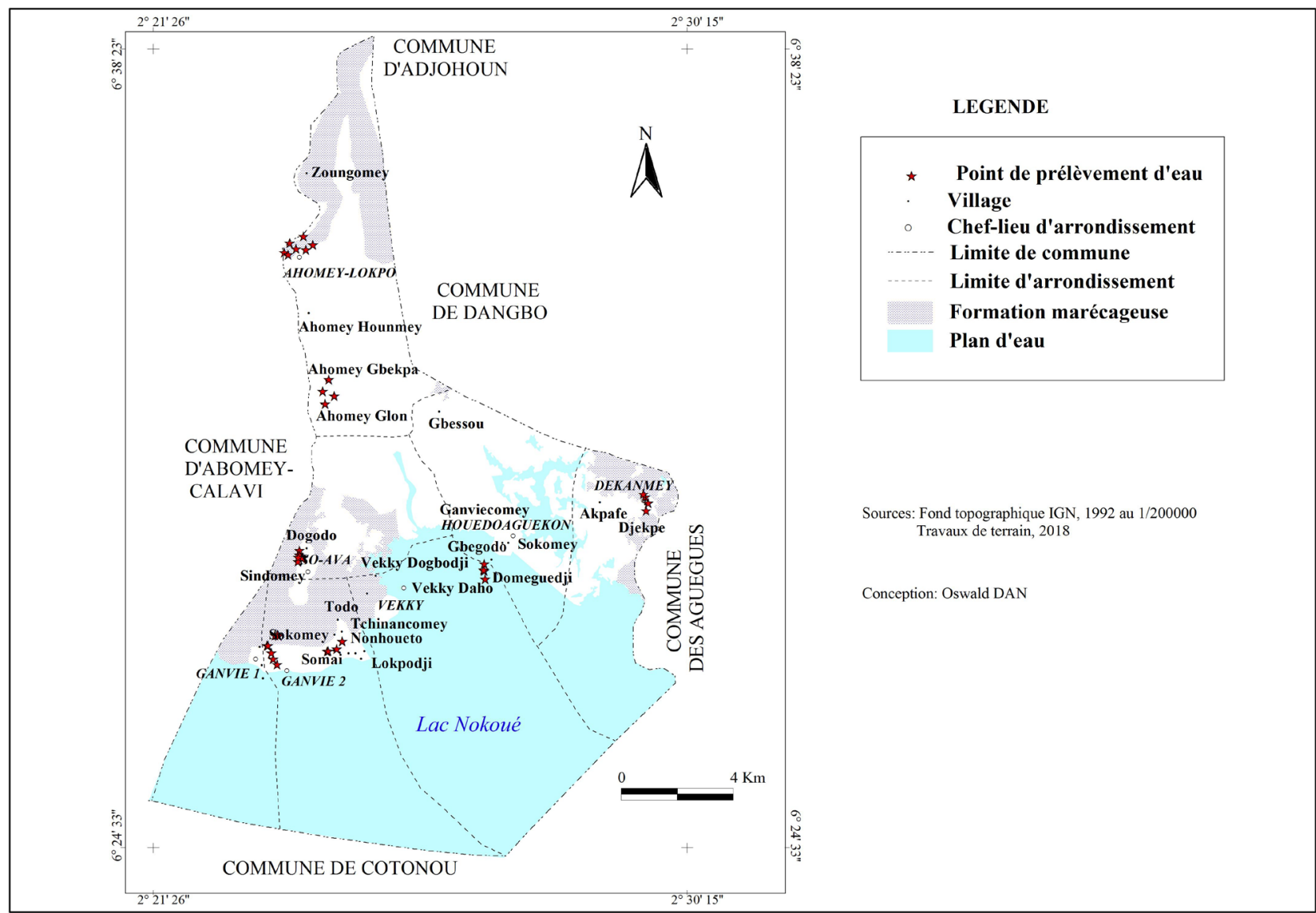

Figure 1. Samples collection points at Sô-Ava. Source: Field Investigations, 2016.

and residual chlorine were determined by colorimetric assay using a spectrophotometer (DR/2800). The reagents used were HACH kits. The chemical reactions involved were: the cadmium reduction method with Nitra Ver 5 for nitrates, the diazotisation method with Nitri Ver 3 for nitrites, the NESSLER method Rochelle salt polyvinyl alcohol for ammonium, the SulfaVer 4 method (reagents in capsules) thanks to the barium for the sulphates, PhosVer 3 method for the ortho-phosphate which reacts with the molybdate in acid medium to produce blue coloration, the phenantroline method -1.10 for the iron whose reaction forms an orange-red complex, the SPANDS method for fluoride, the reaction of which forms a coloring solution with zirconium red and then the DPD method for the determination of chlorine.

\section{Bacteriological analyses}

The bacteriological quality of the water was determined by the search and enumeration of the following bacteria: total mesophilic aerobic organisms, faecal coliforms, Escherichia coli and faecal enterococci. The methods and techniques used to identify different germs in water samples are summarized in Table 1.

\subsubsection{Statistical Analyses}

The results were entered into the Excel spreadsheet and then processed with the XLSTAT 17 statistical software. Descriptive statistics (maximum, minimum, 
Table 1. Summary of research methods and identification of different germs in water samples.

\begin{tabular}{|c|c|c|c|c|}
\hline Parameters searched & Types of seeding & Culture media & $\begin{array}{c}\text { Temperature } \\
\text { and culture time }\end{array}$ & Enumeration \\
\hline $\begin{array}{c}\text { Aerobic flora revivable } \\
\text { (FAR) }\end{array}$ & $\begin{array}{c}\text { Direct } \\
\text { inoculation } \\
\text { of } 1 \mathrm{ml}\end{array}$ & $\begin{array}{c}\text { PCA (Plate Count } \\
\text { Agar) }\end{array}$ & $37^{\circ} \mathrm{C} / 48 \mathrm{H}$ & All colonies \\
\hline Fecal coliforms & & TTC tergitol7 & $44^{\circ} \mathrm{C} / 24 \mathrm{H}$ & $\begin{array}{l}\text { Yellow } \\
\text { colonies }\end{array}$ \\
\hline E. coli & $\begin{array}{c}100 \mathrm{ml} \text { filtration } \\
\text { on } 0.22 \mu \mathrm{m}\end{array}$ & E. coli Rapid Agar & & Violet colonies \\
\hline Fecal streptococci & membrane & $\begin{array}{c}\text { Slanetz and } \\
\text { Bartley } \\
\text { Enterococci }\end{array}$ & $36^{\circ} \mathrm{C} / 24 \mathrm{H}$ & Red colonies \\
\hline
\end{tabular}

mean and standard deviation) of the quantitative variables presented for each parameter correspond to the mean value calculated at from the data recorded during the two sampling campaigns.

\section{Results}

\subsection{Physicochemical Parameters}

The physicochemical parameters determined are: temperature, hydrogen potential, electrical conductivity, total dissolved solids (TDS) and turbidity for the physical parameters then nitrite $\left(\mathrm{NO}_{2}^{-}\right)$, nitrate $\left(\mathrm{NO}_{3}^{-}\right)$, ammonium $\left(\mathrm{NH}_{4}^{+}\right)$, sulphates $\left(\mathrm{SO}_{4}^{2-}\right)$, ortho-phosphates $\left(\mathrm{PO}_{4}^{3-}\right)$, fluorides $\left(\mathrm{F}^{-}\right)$, iron $(\mathrm{Fe})$ and chlorine. The results are shown in Table 2.

The temperatures of the water samples taken varied between $28.80^{\circ} \mathrm{C}$ and $30.8^{\circ} \mathrm{C}$ in rainy season and between 29.1 and 29.8 in dry season. The $\mathrm{pH}$ was between 6.05 and 8.38 in rainy season and between 4.70 and 7.30 in dry season. However, in dry season, 27 of the 36 samples analyzed had $\mathrm{pH}$ values below 6.5 . This shows that nearly $75 \%$ of the water consumed by the population during this period is acidic. The conductivity of all the water samples during the two campaigns is between 7.9 and $649 \mu \mathrm{s} / \mathrm{cm}$. The total dissolved solids present in almost all the samples vary between 4 and $324.50 \mathrm{mg} / \mathrm{L}$. As for the turbidity, the contents obtained during the two campaigns are between 0.03 and 114 NTU.

The maximum values recorded for nitrite compounds $\left(\mathrm{NO}_{2}^{-}\right)$and nitrates $\left(\mathrm{NO}_{3}^{-}\right)$are $1.89 \mathrm{mg} / \mathrm{L}$ and $17.1 \mathrm{mg} / \mathrm{L}$, respectively. The ammonium $\left(\mathrm{NH}_{4}^{+}\right)$concentrations obtained for all the first-season samples do not exceed the standard of $0.5 \mathrm{mg} / \mathrm{L}$, as opposed to $22 \%$ of the samples taken during the second campaign. The highest levels observed for sulphate $\left(\mathrm{SO}_{4}^{2-}\right)$, ortho-phosphate $\left(\mathrm{PO}_{4}^{3-}\right)$ and fluoride $\left(\mathrm{F}^{-}\right)$are respectively $24.52-3$ and $0.80 \mathrm{mg} / \mathrm{L}$. Concerning the iron $(\mathrm{Fe})$, the values obtained during the two campaigns vary between 0.01 and $4.52 \mathrm{mg} / \mathrm{L}$. Approximately $32.25 \%$ and $47.22 \%$ of the samples taken during the first and second campaigns were greater concentration of iron than the 
Table 2. Comparison of the physicochemical results of the water taken during the two seasons.

\begin{tabular}{|c|c|c|c|c|c|c|c|c|c|c|c|c|c|c|}
\hline & Statistic & $\mathrm{T}$ & $\mathrm{pH}$ & $\mathrm{CE}$ & TDS & NTU & $\mathrm{NO}_{2}^{-}$ & $\mathrm{NO}_{3}^{-}$ & $\mathrm{NH}_{4}^{+}$ & $\mathrm{SO}_{4}^{2-}$ & $\mathrm{PO}_{4}^{3-}$ & $\mathrm{Fe}$ & $\mathrm{F}^{-}$ & $\mathrm{Cl}$ \\
\hline \multirow{4}{*}{$\begin{array}{l}\text { Rainy } \\
\text { season }\end{array}$} & Minimum & 28.8 & 6.05 & 7.9 & 4 & 0.03 & 0 & 0.89 & 0.01 & 0.07 & 0.06 & 0.01 & 0.01 & 0 \\
\hline & Maximum & 30.8 & 8.38 & 649 & 324.5 & 29.4 & 1.89 & 17.1 & 2.89 & 19.18 & 1.98 & 3.19 & 0.8 & $10^{-1}$ \\
\hline & Moyenne & 29.71 & 7.27 & 174.83 & 87.4 & 4.31 & 0.11 & 5.06 & 0.34 & 3.25 & 0.48 & 0.4 & 0.31 & $3.75 \cdot 10^{-3}$ \\
\hline & $\begin{array}{c}\text { Standard } \\
\text { deviation }(n-1)\end{array}$ & 0.39 & 0.55 & 152.9 & 76.44 & 6.83 & 0.36 & 5.53 & 0.54 & 5.01 & 0.45 & 0.65 & 0.2 & $1.79 \cdot 10^{-2}$ \\
\hline \multirow{4}{*}{$\begin{array}{c}\text { Dry } \\
\text { season }\end{array}$} & Minimum & 29.1 & 4.7 & 30.3 & 15.2 & 0.87 & 0 & 0.18 & 0 & 0.04 & 0.05 & 0.01 & 0 & 0 \\
\hline & Maximum & 29.8 & 7.3 & 565 & 283 & 114 & 0.06 & 8.32 & 14.02 & 24.52 & 3 & 4.52 & 0.74 & $2.5 \cdot 10^{-1}$ \\
\hline & Moyenne & 29.41 & 6.16 & 135.56 & 68.09 & 7.86 & 0.01 & 2.46 & 1.3 & 4.91 & 1.03 & 0.59 & 0.34 & $3.42 \cdot 10^{-2}$ \\
\hline & $\begin{array}{c}\text { Standard } \\
\text { deviation }(n-1)\end{array}$ & 0.19 & 0.59 & 132.31 & 66.13 & 20.35 & 0.01 & 1.87 & 3.53 & 6.64 & 1.03 & 0.86 & 0.23 & $7.39 \cdot 10^{-2}$ \\
\hline
\end{tabular}

allowed value of $0.3 \mathrm{mg} / \mathrm{L}$. Residual chlorine dosage values obtained for the study range from 0 to $0.25 \mathrm{mg} / \mathrm{L}$ with no total chlorine in all samples taken from the sample within households (storage phase). From a total of 22 sources, the results indicate that with the exception of $45 \%$ of samples with concentrations between 0.02 and $0.25 \mathrm{mg} / \mathrm{L}$, no remaining chlorine was detected in the remaining samples.

\subsection{Bacteriological Parameters}

The results of the bacteriological analyses of the sampled stations are shown in Table 3.

The results from the bacteriological analyses carried out during the two campaigns reveal a total germ content between 0 and $2.58108 \mathrm{CFU} / 1 \mathrm{ml}$. Indeed, it was noted a presence of banal bacteria in $97 \%$ and $83 \%$ of the water taken respectively in rainy season and dry season.

The presence of fecal pollution indicator germs such as faecal coliforms, Escherichia coli and faecal streptococci has been shown to be positive in the majority of samples taken when none of these organisms must be contained in water in accordance with the standard WHO and that in force in Benin.

The counts of thermotolerant coliforms in water samples ranged from 0 to 6.8 $104 \mathrm{CFU} / 100 \mathrm{~mL}$. From the 67 water samples collected in the municipality of Sô-Ava, 82\% contain total coliforms between 2 and $6.8104 \mathrm{CFU} / 100 \mathrm{~mL}$ while $18 \%$ have a good bacteriological quality with absence of coliforms totals.

The detection of Escherichia Coli, a fecal bacterium which is pollution indicator, confirms the contamination of $51 \%$ of the water samples during both campaigns. Among these $51 \%$ polluted samples, it was found that $45 \%$ comes from the water taken from households while $6 \%$ comes from sources of supply.

The analyses of faecal enterococci showed that $70 \%$ of the samples are contaminated. The concentration of faecal enterococci varies between 00 and 3.3104 CFU/100 mL. 
Table 3. Comparison of the bacteriological results of the water taken during the two seasons.

\begin{tabular}{lccccc}
\hline & Statistic & $\begin{array}{c}\text { Total } \\
\text { Sprouts/1 } \mathrm{mL}\end{array}$ & $\begin{array}{c}\text { Thermotolerant } \\
\text { coliforms } / 100 \mathrm{~mL}\end{array}$ & $\begin{array}{c}\text { Escherichia } \\
\text { coli/ } 100 \mathrm{~mL}\end{array}$ & $\begin{array}{c}\text { Faecal enterococci/ } \\
100 \mathrm{~mL}\end{array}$ \\
\hline & Minimum & 00 & 00 & 00 & 00 \\
$\begin{array}{c}\text { Rainy } \\
\text { season }\end{array}$ & Maximum & $2.56 \cdot 10^{8}$ & $8.42 \cdot 10^{3}$ & $1.22 \cdot 10^{3}$ & $3.50 \cdot 10^{3}$ \\
& Mean & $8.80 \cdot 10^{6}$ & $1.55 \cdot 10^{3}$ & $1.38 \cdot 10^{2}$ & $3.46 \cdot 10^{2}$ \\
& $\begin{array}{c}\text { Standard } \\
\text { deviation (n }-1)\end{array}$ & $4.51 \cdot 10^{7}$ & $2.30 \cdot 10^{3}$ & $2.69 \cdot 10^{2}$ & $7.15 \cdot 10^{2}$ \\
& Minimum & 00 & 00 & 00 & 00 \\
Dry & Maximum & $9 \cdot 10^{6}$ & $6.8 \cdot 10^{4}$ & $8 \cdot 10^{3}$ & $3.3 \cdot 10^{4}$ \\
Season & Moyenne & $1.82 \cdot 10^{6}$ & $1.12 \cdot 10^{4}$ & $3.79 \cdot 10^{2}$ & $2.31 \cdot 10^{3}$ \\
& Standard & $2.70 \cdot 10^{6}$ & $1.99 \cdot 10^{4}$ & $1.42 \cdot 10^{3}$ & $6.83 \cdot 10^{3}$ \\
\hline
\end{tabular}

\section{Discussion}

\subsection{Physicochemical Parameters}

The results of the physico-chemical analysis of the water samples show that the average temperature values are $29.71 \pm 0.39$ in the rainy season and $29.41 \pm 0.19$ in the dry season. The small variation in water temperature is due to daily climatic variations and exposure to the sun's rays. The results of our study corroborate those of [13] who obtained temperatures ranging between 28 and $32^{\circ} \mathrm{C}$ for drinking water in two localities of Benin: Cotonou and Dassa-Zoumè. WHO recommends no value since the temperature of the water has virtually no direct impact on human health. However, a water temperature between 25 and $28^{\circ} \mathrm{C}$ is a culture medium conducive to microorganisms. Rising water temperatures create favorable conditions for tropical water pollution [14].

$\mathrm{pH}$ is one of the important parameters that can tell if a water is acidic or alkaline. It conditions the physico-chemical equilibria, especially the calco-carbonic equilibrium (the action of water vis-à-vis carbonates). Its variation is related to that of salinity, temperature and $\mathrm{CO}_{2}$ concentration [15]. The average $\mathrm{pH}$ values recorded during our work are respectively $7.27 \pm 0.55$ in the rainy season and $6.16 \pm 0.59$ in the dry season. Most of the $\mathrm{pH}$ values obtained during the dry season show an acidity that tends towards a slight neutrality during the rainy season. Most of the waters in this study indicate $\mathrm{pH}$ near neutrality with a slightly dominant acidic character. The results are very close to those measured by [1] [16] for well water in the Berrahal region of Algeria and in the municipality of Pobè in Benin. All waters comply with standards accepted in Benin and those of the WHO, which can not pose health risks. However, it should be emphasized that WHO recommends a $\mathrm{pH}$ of less than 8 for good disinfection by chlorine [12].

Electrical conductivity is the ability of an aqueous solution to conduct electrical current [17]. It makes it possible to determine the total content of the minerals present in a water. The analyzed waters have an average electrical con- 
ductivity of $174.83 \pm 152.9 \mu \mathrm{s} / \mathrm{cm}$ in the rainy season then $135.56 \pm 132.31$ in the dry season. Indeed, the conductivity values reflect a low mineralization of water that is similar to that measured by [16] in the municipality of Pobè in Benin. It should be mentioned that our results comply with the standards in force for drinking water in the Republic of Benin and those of the WHO. [18] reports that the change in conductivity is induced by the presence in the medium ions that are mobile in an electric field. This mobility depends on the nature of the dissolved ions and their concentration, such as calcium $\left(\mathrm{Ca}_{2}^{+}\right)$, sodium $\left(\mathrm{Na}^{+}\right)$, chloride $\left(\mathrm{Cl}^{-}\right)$, bicarbonates $\left(\mathrm{HCO}_{3}^{-}\right)$, etc.

The mean values of Total Dissolved Solids (TDS) are $87.40 \mathrm{mg} / \mathrm{L} \pm 76.44 \mathrm{dur}$ ing the rainy season and $68.09 \pm 66.13$ during the dry season. These results are also close to the findings of [5] in the municipality of Zè, Benin where TDS varies between 9 and $82.9 \mathrm{mg} / \mathrm{L}$. The maximum concentration allowed by the WHO is $1000 \mathrm{mg} / \mathrm{L}$ and $2000 \mathrm{mg} / \mathrm{L}$ by the Beninese regulations.

The turbidity of a water is due to the presence of finely divided suspended matter: clays, silts, silica grains, organic matter, etc. [19]. The concentrations obtained for turbidity are $4.31 \pm 6.83$ in the rainy season and $7.86 \pm 20.35 \mathrm{NTU}$ in dry season. Turbidity greatly affects the potability of drinking water and is a gene for the effectiveness of microbial decontamination treatments [20]. Consumers very often have requirements in relation to this parameter. The WHO recommends a limit value of 5 NTU but specifies that in the case of disinfection, the turbidity should be less than 1 NTU [18]. However, turbidity greater than 5 NTU would limit the destruction of coliforms because suspended particles can lead to unpleasant tastes and odors [12].

\section{Ammonium ( $\mathbf{N H}_{4}^{+}$)}

Ammonium in water usually reflects a process of incomplete degradation of organic matter [21]. The presence of ammonia in significant quantity is the index of a contamination by discharges of human or industrial origin. In fact, human or animal urines contain large amounts of urea which is transformed into ammonia [22]. In general, ammonium is converted rather quickly into nitrites and nitrates by oxidation. WHO recommends a limit value of $0.5 \mathrm{mg} / \mathrm{L}$ for ammonium $\left(\mathrm{NH}_{4}^{+}\right)$. For the analyzed samples, the ammonium contents during the two campaigns vary between 0 and $14.02 \mathrm{mg} / \mathrm{L}$ with $19.4 \%$ of samples not respecting the norms of potability of WHO. The presence of ammonium in water results from surface contamination mainly related to domestic effluent discharges and then to decomposing organic matter. The results of our study are contrary to those obtained by [20] [23] whose highest concentrations are respectively $0.07 \mathrm{mg} / \mathrm{L}$ and $0.028 \mathrm{mg} / \mathrm{L}$ for the waters of the river Gombe in Congo and the city of Batna in Algeria.

\section{Nitrates $\left(\mathrm{NO}_{3}^{-}\right)$}

Nitrates are the final stage of nitrogen oxidation and serve as an overall indicator of degradation of the natural quality of water. They come from the nitrification of soil, the decomposition of organic matter (oxidation) or in large quantities from nitrogenous agricultural fertilizers or in a small proportion from ni- 
trogenous minerals. It is a relatively stable ion, very soluble in water, which in a reducing medium can pass into nitrites or ammonium [15] [22]. With regard to the samples taken during the two seasons, the values vary between 0.89 and 17.1 $\mathrm{mg} / \mathrm{L}$. The values obtained are significantly lower than the guidelines in force in Benin and those established by the WHO which set a maximum threshold of 50 $\mathrm{mg} / \mathrm{L}$. the values obtained confirm the poor practice of agricultural activities in the municipality of Sô-Ava. It could therefore be predicted that these waters do not present health risks for the consumer with regard to nitrate concentration $\left(\mathrm{NO}_{3}^{-}\right)$.

\section{Nitrite $\left(\mathrm{NO}_{2}^{-}\right)$}

Nitrites come either from an incomplete oxidation of ammonia or a reduction of nitrates under the influence of a denitrifying action of bacteria (denitrification phenomenon) [18] [20]. In our study, nitrite values range from 0 to $1.90 \mathrm{mg} / \mathrm{L}$. Only $4.48 \%$ of the water samples contain nitrite levels above the guideline of 0.1 $\mathrm{mg} / \mathrm{L}$ admitted by the WHO and almost all the samples comply with the regulations in force in Benin, which is $3.2 \mathrm{mg} / \mathrm{L}$. Water containing nitrites is considered suspect because it is often associated with a deterioration of microbiological quality [18].

Studies conducted by [24] have shown that nitrites are non-existent in borehole and tank water with the exception of streams where a concentration of 0.5 $\mathrm{mg} / \mathrm{L}$ has been observed. The presence of nitrite in significant quantities degrades the quality of water and could affect human health [25]. Nitrites react with hemoglobin in erythrocytes to form methemoglobin, which affects the blood' ability to carry enough oxygen to the cells in the body [26].

\section{Orthophosphates $\left(\mathbf{P O}_{4}^{3-}\right)$}

The presence of phosphates in the water is often due to urine and faeces released by animals and humans, discharges of domestic wastes water and the use of phosphate fertilizers [27]. The orthophosphate concentrations recorded during our work range from $0.05 \mathrm{mg} / \mathrm{L}$ to $3 \mathrm{mg} / \mathrm{L}$ and are lower than the guideline allowed in Benin which is $5 \mathrm{mg} / \mathrm{L}$. The doses of orthophosphate obtained in our work do not appear to pose a direct risk to human health.

\section{Iron (Fe)}

Iron is a metal found naturally in rocks and groundwater. Its presence in water can change the taste, smell and color of water [28]. This is an element that is present in all our samples at concentrations ranging from 0.01 to $4.52 \mathrm{mg} / \mathrm{L}$. About $40 \%$ of the samples do not comply with WHO standards and those in force in Benin that are $0.3 \mathrm{mg} / \mathrm{L}$ in drinking water. However, there is little variability in average levels obtained during the rainy season $(0.40 \mathrm{mg} / \mathrm{L} \pm 0.65)$ and then in the dry season $(0.59 \mathrm{mg} / \mathrm{L} \pm 0.86)$. Our results differ from those of [20] which recorded a maximum concentration of $0.116 \mathrm{mg} / \mathrm{L}$ in the waters analyzed in Batna in Algeria according to the WHO standard.

It should be noted that people are often reluctant to the consumption of ferruginous water because it blushes very quickly and does not cook easily food. This situation was particularly evoked during our surveys by households in the 
Ahomey-Lokpo district, for this reason, they prefer to resort to another surface water source which is far better. Recent studies have found that iron in the concentrations usually found in water does not present a health risk [28].

\section{Sulphates ( $\mathbf{S O}_{4}^{2-}$ )}

Sulphate is a major component of dissolved compounds found naturally in natural waters. The sulphate can be attacked by a bacterium that reduces it to hydrogen sulphide $\left(\mathrm{H}_{2} \mathrm{~S}\right)$. The sulphate levels in the waters analyzed for the two campaigns are between 0.04 and $24.52 \mathrm{mg} / \mathrm{L}$ and are in conformity with the standard of $250 \mathrm{mg} / \mathrm{L}$ fixed by the WHO and that of $400 \mathrm{mg} / \mathrm{L}$ require by Benin standards.

Normal levels of sulphates and hydrogen sulphide have no effect on those who ingest these substances. However, high concentrations of sulphate in drinking water can have a significant laxative effect combined with calcium and magnesium which could lead to gastrointestinal disorders in the consumer. As a safety measure, water with a sulfate level exceeding $400 \mathrm{mg} / \mathrm{L}$ should not be used for the preparation of baby food [29].

\section{Fluorides $\left(\mathrm{F}^{-}\right)$}

Fluoride is a trace mineral that contributes to the strength of the skeleton and the prevention of dental caries by strengthening tooth enamel. The results of water analyses show that the maximum fluoride concentration observed in our work is $0.8 \mathrm{mg} / \mathrm{L}$ and does not exceed the drinking water standard of $1.5 \mathrm{mg} / \mathrm{L}$ admitted by the WHO. The various levels recorded in our work seem to present no health risks for consumers. However, it should be emphasized that in small doses ( $1 \mathrm{mg} / \mathrm{L}$ in drinking water), fluoride promotes dental health. When concentrations are higher than $1.5 \mathrm{mg} / \mathrm{L}$, this causes dental fluorosis, which is a change in dental enamel causing yellow or brown stains [30]. A concentration higher than $5 \mathrm{mg} / \mathrm{L}$ may cause tooth loss and bone fluorosis characterized by bone hypercalcification. In case of prolonged exposure where the concentration of fluoride ion is ten times higher than the accepted norm, this can present a significant danger of intoxication [30].

\section{Residual chlorine $(\mathrm{Cl})$}

Residual chlorine is essential to ensure the safety of drinking water. It is a powerful oxidizer, which, when mixed with water, burns the organic matter it contains, especially pathogenic viruses and microbes in half an hour. The free chlorine concentration of the treated water must be 0.2 to $0.5 \mathrm{mg} / \mathrm{L}$ according to the WHO, while the Beninese standard recommends a content of chlorine between 0.1 and $0.3 \mathrm{mg} / \mathrm{L}$. WHO points out that taste and odor problems can occur for consumers at concentrations of 0.6 to $1 \mathrm{mg} / \mathrm{L}$. When the concentration of chlorine in the water is around 2 to $3 \mathrm{mg} / \mathrm{L}$, people can smell an irritating odor [31].

In the present study, chlorine was only detected in $14.93 \%$ of samples with $8.95 \%$ of samples that comply with standards in force in Benin (0.1 to $0.3 \mathrm{mg} / \mathrm{L}$ ). However, it should be noted that the maximum concentration does not exceed $0.25 \mathrm{mg} / \mathrm{L}$ in all the samples. Several studies in developing countries have shown that chlorination of drinking-water at home reduces the incidence of diarrheal 
diseases $20 \%-48 \%$ [32]. It is also one of the most effective home-based interventions for preventing diarrheal diseases in a large number of countries [33]. Samples with a residual chlorine content that does not comply with the standards in force in Benin and WHO represent $85.07 \%$. The absence or low levels of residual chlorine observed in our samples could be related to insufficient chlorination of the treated water or frequent breaks in the pipes. However, studies conducted by [34] on laboratory animals and humans indicated that chlorine has low toxicity, regardless of the route of exposure (i.e. by ingestion, inhalation) or cutaneous absorption. No adverse health effects other than taste and odor were observed in humans who consumed high chlorinated water for a short period of time (up to $50 \mathrm{mg} / \mathrm{L}$ of chlorine).

\subsection{Bacteriological Parameters}

\section{Total sprouts}

The enumeration of optional aerobic and anaerobic mesophilic bacteria is designed to estimate the density of the general bacterial population in drinking water. It allows an overall assessment of the general safety of a water, without specifying the sources of contamination [35]. In general, the presence of total germs does not have direct effects on health but is used as an indicator of pollution and treatment efficacy [17].

The results of this study indicate respectively that $96.77 \%$ and $83.33 \%$ of the samples taken in the rainy season and dry season are contaminated by the total seeds whose maximum concentration reaches $2.56 \cdot 10^{8} \mathrm{CFU}$. The number of common bacteria contained in these waters far exceeds the standard in force in Benin, which is 20 germs/mL maximum for treated water and less than 50 germs $/ \mathrm{mL}$ for untreated water. The results of our work corroborate those found by [5] in Benin; [17] [36] in Algeria. The observation of the results obtained makes it possible to say that the risk of water contamination by sprouts is higher in the rainy season than in the dry season. The high contamination of the waters by the total germs could probably be due to: the obsolescence of the pipes, the lack of hygiene around the water points, the surrounding pollution (presence of the wild dumps, the straying of the animals, the defecation to the open air, ...).

\section{Faecal coliforms}

Faecal or thermotolerant coliforms are generally found in human or animal faeces, wastewater, polluted surface water. Their density is generally proportional to the degree of pollution produced by the faeces. They are good indicators of the effectiveness of water treatment, but since they are less numerous than total coliforms, they are preferable for this function (Robertson, 1995) cited by [35].

The results of our work show that only $9.67 \%$ and $25 \%$ of water samples taken successively in the rainy season and then in the dry season are free of faecal germs. In the rainy season, the number of fecal germs varies between 0 and $8.42 \cdot 10^{3} \mathrm{CFU}$ for an average of $1.55 \cdot 10^{3} \pm 2.30 \cdot 10^{3} \mathrm{CFU}$ while in the dry season, the rate is between 0 and $6.8 \cdot 10^{4} \mathrm{CFU}$ for an average of $1.12 \cdot 10^{4} \pm 1.99 \cdot 10^{4}$. It should be noted that pollution is preponderant during transport and storage of 
water at home since, with the exception of a sample made within household, all other samples free of germs were observed at the source. Statistics reveal that more than $82.09 \%$ of all water samples are contaminated with faeces of human origin. These values do not comply with WHO standards and those in force in Benin which provides for 0 faecal coliforms in $100 \mathrm{ml}$ of sample. Our results are similar to those of [37] in Morocco and [19] in Mali, which also found values above the limit advocated by the WHO, which allows us to deduce that these waters are unfit for human consumption.

\section{Fecal coliforms (Escherichia coli)}

The species most frequently associated with the fecal coliform group is Escherichia coli and to a lesser extent some species of the genera Citrobacter, Enterobacter and Klebsiella. However, E. coli accounts for $80 \%$ to $90 \%$ of the thermotolerant coliforms detected and provides clear evidence of recent faecal pollution [35] [38]. This microorganism originates exclusively from the intestines of warm-blooded animals, including humans, should be totally absent from drinking water [17].

Microbiological analysis of the waters of Sô-Ava showed that in the rainy season, the number of $E$. coli varies from 0 to $1.22 \cdot 10^{3} \mathrm{CFU}$ with an average of $1.38 \cdot 10^{2} \mathrm{CFU} \pm 2.69 \cdot 10^{2}$ while in the dry season, the proportion is included in the margin from 0 to $8 \cdot 10^{3} \mathrm{CFU}$ for an average of $3.79 \cdot 10^{2} \mathrm{CFU} \pm 1.42 \cdot 10^{3}$. Our analyses show that $50.75 \%$ of these waters contain E. coli and are therefore not drinkable to the extent that $\mathrm{WHO}$ and Beninese standards require the complete absence of these germs in water intended for consumption. This high concentration of faecal coliforms (E. coli) in the study environment is close to that found by [37] in Morocco. According to the surveys in the sites of the controlled wells, this contamination is due to the practices of defecation in the open air and in the water by the populations as well as the animals in rambling. Although not all $E$. coli are pathogenic, gastroenteritis is the most common disease associated with the ingestion of faecally contaminated water as it has very serious health consequences [39].

\section{Fecal enterococci}

Faecal enterococci are sensitive, specific and fairly resistant fecal contamination. They do not usually have significant pathogenicity. Streptococcus faecalis is omnipresent (ubiquitous) in the large intestine of humans and animals and sewers [20]. [18] reports that the detection of fecal enterococci is strongly associated with the presence of faecal coliforms (E. coli) and indicates faecal contamination of feed water. According to Youmbi et al., 2013 reported by [17] the presence of faecal streptococci is a sign of faecal contamination of water, making them a prime indicator for evaluating the efficacy treatment of contaminated water. The concentration of these germs in these waters oscillates between 0 and 3.5.10 $\mathrm{CFU}$ with an average of $3.46 \cdot 10^{2} \mathrm{CFU} \pm 7.15 \cdot 10^{2}$. These waters containing faecal streptococci are therefore unfit for human consumption since they are not in line with WHO standards and those in force in Benin that require a complete absence of this flora in water intended for consumption. This pollution could be 
explained by the rejection of faeces of animals that are strayed throughout the municipality of Sô-Ava, the proliferation of wild dumps strewing alleys and streets. Our results are contrary to those obtained by [40] who recorded a total absence of faecal streptococci in the treated waters, in the waters of the $\mathrm{Si}$ di-Moussa reservoir and in the waters distributed to the populations of the commune of Sidi-Moussa, Tipaza in Algeria. According to the work of [41] there is an increased risk of developing gastroenteritis with a relatively small number of faecal streptococci (3 to 10 bacteria $/ 100 \mathrm{~mL}$ ) present in the water.

\section{Conclusion}

Analysis of the physicochemical parameters of the waters of the commune of Sô-Ava during the study period may be considered admissible and present no danger for consumers. From the bacteriological point of view, the results of the work show that only $89.55 \%$ of the water drawn is of dubious quality and therefore does not comply with the water quality standards recommended by the World Health Organization (WHO) and the Republic of Benign. The study was conducted over two seasons (rainy and dry), it was noticed that the bacteriological pollution is particularly accentuated during the rainy season. This situation could be explained by the fact that during this period of the year the humidity is favorable for the survival and proliferation of pathogenic microorganisms. As a result, the use of water unfit for consumption is undoubtedly a risk to the health of the population. This situation could lead to the spread of many infectious and parasitic diseases involving into water transport, in particular: cholera, typhoid, hepatitis, dysentery, gastroenteritis, diarrheal diseases, schistosomiasis and malaria [42] [43]. As such, it is important to carry out periodic analyses to monitor the evolution of the quality of the drinking water in order to prevent its contamination and preserve the health of the populations.

\section{Acknowledgements}

Our sincere thanks to the International Foundation for Science (IFS) for contributing to this work.

\section{Conflicts of Interest}

The authors declare that they have no conflict of interest for this article.

\section{References}

[1] Kahoul, M., Derbal, N., Alioua, A. and Ayad, W. (2014) Evaluation of the Physicochemical Quality of Well Water in the Berrahal Region (Algérie). LARHYSS Jour nal, 18, 169-178.

[2] Tamungang, N.E.B., Biosengazeh, N.F., Alakeh, M.N. and Tameu, D.Y. (2016) Quality Control of Domestic Water in Babessi Village in Northwestern Cameroon. International Journal of Biological and Chemical Sciences, 10, 1382-1402. https://doi.org/10.4314/ijbcs.v10i3.37

[3] WHO/UNICEF (2015) 2015 Progress Report on Sanitation and Water Supply: The 
Key Facts. WHO, Geneva.

[4] Nafi, A. (2006) Multi-Year Program for the Renewal of Drinking Water Networks. PhD Thesis, University Louis Pasteur Strasbourg I, Strasbourg, France.

[5] Odoulami, L., Gbesso, F. and Hounguevou, S. (2013) Quality of Water Consumption and Waterborne Diseases in the Municipality of Ze (Benin). Rev geography from Environment, 2, 104-113.

[6] Municipality of Sô-Ava (2014) Communal Water Program 2015-2017, Provisional Version. Municipality of Sô-Ava, Benin.

[7] Ahoyo, T.A., Fatombi, K.J., Boco, M., Aminou, T. and Dramane, K.L. (2011) Impact of Water Quality and Sanitation on the Health of Children in Suburban Areas in Benin: The Case of Health Zones Savalou-Banté and Dassa-Glazoué. Médecine Tropicale, 71, 281-285.

[8] Besancenot, J.P., Handschumacher, P., Ndione, J.A., Mbaye, I. and Laaidi, K. (2004) Climate, Water and Health in the West African Sahel. Drought, 15, 33-41.

[9] INSAE (2002) Second General Census of Population and Housing (Synthesis of the Results of Analysis). National Institute of Statistics and Economic Analysis, Benin.

[10] INSAE Bénin (2013) Résultats provisoires du RGPH4. http://www.insae-bj.org/recensement-population.html

[11] Municipality of Sô-Ava (2006) Communal Monograph of So-Ava. Municipality of Sô-Ava, Benin.

[12] Rodier, J., Legube, B. and Merlet, N. (2009) Water Analysis. Dunod, Paris.

[13] Gbohaida, V., Agbangnan, D.P., Ngossanga, M.B., Medoatinsa, S.E., Dovonon, L.F., Wotto, D.V., Avlessi, F. and Sohounhloue, D.C. (2016) Study of the Physico-Chemical Quality of Drinking Water in Two Localities of Benin: Cotonou and Dassa-Zoumè. International Journal of Biological and Chemical Sciences, 10, 422-434. https://doi.org/10.4314/ijbcs.v10i1.32

[14] Makoutode, M., Assani, A.K., Ouendo, E.M., Agueh, V.D. and Diallo, P. (1999) Quality and Method of Management of Well Water in Rural Benin: Case of the Sub-Prefecture of Grand-Popo. Medicine of Black Africa, 46, 528-534.

[15] Abbou, B., Fadil, F., El Haji, M. and Zemzami, M. (2014) Anthropogenic Impact on Groundwater Quality in the Watershed of Oued Taza (morocco). European Scientific Journal, 10, 1857-7881.

[16] Lagnika, M., Ibikounle, M., Montcho, J.C., Wotto, V.D. and Sakiti, N.G. (2014) Evaluation of the Physicochemical Quality of Well Water in the Berrahal Region. Journal of Applied Biosciences, 79, 6887-6895.

[17] Ayad, W. and Kahoul, M. (2016) Assessment of Physico-Chemical and Bacteriological Quality of Well Water in the Region of El-Harrouch (NE-Algeria). Journal of Materials and Environmental Science, 7, 1288-1297.

[18] Rodier, J., Bazin, C., Chambon, P., Champsaur, H. and Rodi, L. (2005) Analysis of Water, Natural Waters, Wastewater, Seawater, Chemistry, Physico-Chemistry, Microbiology, Biology, Interpretation of Results.

[19] Coulibaly, K. (2005) Study of the Physicochemical and Bacteriological Quality of Well Water in Certain Districts of Bamako District. PhD Thesis in Pharmacy, Faculty of Medicine, Pharmacy and Odontostomatology of the University of Bamako, Bamako.

[20] Baziz, N. (2008) Study on the Quality of Drinking Water and Potential Health Risks: Case of the City of Batna (Memory of Magister in Dynamics of Physical Environments and Natural Risks). Faculty of Sciences, Colonel El Hadj Lakhdar Uni- 
versity, Batna.

[21] Chia, E. and Croset, N.R. (1994) Agriculture and Water Quality: Negotiation and the Role of Research. Studies Rech. about Agrarian Systems Dev., 177-193.

[22] Girgenti, P. (2011) Analyses Physico-Chimiques.

[23] Akatumbila, L., Mabiala, M., Lubini, A., Pwema, K. and Musibono, E.A. (2016) Contribution to the Evaluation of the Physicochemical Quality of Water: Case of the Urban River Gombe of Kinshasa/Democratic Republic of Congo. Larhyss Journal, No. 26, 7-29.

[24] Gnazou, M.D.T., Assogba, K., Sabi, B.E. and Bawa, L.M. (2015) Physicochemical and Bacteriological Quality of Water Used in Schools in Zio Prefecture (Togo). International Journal of Biological and Chemical Sciences, 9, 504-516. https://doi.org/10.4314/ijbcs.v9i1.43

[25] Belghiti, M., Chahlaoui, A., Bengoumi, D. and El Moustaine, R. (2013) Study of the Physico-Chemical and Bacteriological Quality of the Groundwater of the Plio-Quaternary Aquifer in the Region of Meknes (Morocco). Larhyss Journal, 21-36.

[26] WHO (2017) Water-Related Diseases. http://www.who.int/water_sanitation_health/diseases/methaemoglob/fr/

[27] Hakmi, A. (2006) "Water Treatment" Treatment of Spring Water bousfer ORAN. University of Science and Technology Oran, Algeria.

[28] ASSSCA (2011) What to Do if the Amount of Manganese (Mn) or Iron (Fe) in the Water in Your Well Exceeds the Recommendation?

[29] Lenntech (2017) Sulphates. https://www.lenntech.fr/sulfates.htm

[30] Lounici, H., Adour, L., Grib, H., Belhocine, D. and Mameri, N. (2008) Fluoride in Drinking Water and Fluorosis.

[31] Ouahchia, C., Hamaidi-Chergui, F., Hamaidi, M.S. and Saidi, F. (2014) Preliminary Investigation for Consumer Perceptions of Drinking Water Quality in Tipaza (Algeria). International Journal of Innovation and Applied Studies, 9, 1675-1686.

[32] Crump, J., Otieno, P., Slutsker, L., Keswisck, B., Rosen, D. and Hoekstra, R. (2005) Household Based Treatment of Drinking Water with Flocculant/Disinfectant for Preventing Diarrhoea in Areas with Turbid Source Water in Rural Western Kenya : Cluster Randomised Controlled Trial. BMJ, 331, 478-483. https://doi.org/10.1136/bmj.38512.618681.E0

[33] Ashbolt, N.J. (2004) Microbial Contamination of Drinking Water and Disease Outcomes in Developing Regions. Toxicology, 198, 229-238. https://doi.org/10.1016/j.tox.2004.01.030

[34] Health Canada (2009) Guidelines for Canadian Drinking Water Quality.

[35] Hamdi, W. (2011) Hygienic Quality and Physicochemical Characteristics of Domestic Waters of Some Localities of the Basin of Ouargla (Diploma of Magister in Biology). Kasdi Merbah-Ouargla.

[36] Benouis, K., Benabderrahmane, M., Harrache-Chettouh, D. and Benabdeli, K. (2008) Can We Drink the Waters of Moorish Baths "Hammam"?: Case of the Baths of the City of Sidi-Bel-Abbès. Cah. Santé 18, 4 .

[37] Hayzoun, H., Ouammou, A., Saidi, O. and Khalil, F. (2014) Assessment of the Bacteriological and Chemical Quality of the Sebou River, Morocco. Journal of Materials and Environmental Science, 5, 2438-2443.

[38] WHO (2004) Quality Guidelines for Drinking Water. World Health Organization, Genève. 
[39] Degbey, C., Makoutode, M., Fayomi, B. and De Brouwer, C. (2010) The Quality of Drinking Water in a Professional Environment in Godomey in 2009 in Benin West Africa. Journal International de Santé au Travail, 1, 15-22.

[40] Ouahchia, C., Hamaidi-Chergui, F., Hamaidi, M.S. and Saidi, F. (2015) Bacteriological Quality of the Drinking Water of the Different Reservoirs and Consumers of the Commune of Tipaza Supplied by the Sidi Amar Station from the Surface Water of the Lake-Dam of Boukourdane. LARHYSS Journal, 139-154.

[41] Zmirou, D., Kelley, J.P., Collin, J.F., Charrel, M. and Berlin, J. (1987) A Follow-Up Study of Gastro-Intestinal Diseases Related to Bacteriologically Substandard Drinking Water. American Journal of Public Health, 77, 582-584. https://doi.org/10.2105/AJPH.77.5.582

[42] El Ouali Lalami, A., Merzouki, M., Bennani, L., Maniar, S., Ameziane Hassani, F., EL Harch, M. and Oumokhtar, B. (2008) Bacteriological and Parasitological Study of the Water of the Sebou wadi after Discharge of Wastewater from the City of Fez in Morocco. Trib. Water, 646, 50-55.

[43] Yadouleton, M.J. (2015) Environmental Sanitation in Cotonou and Fight against Cholera (University of Abomey-Calavi). Faculty of Arts, Arts and Humanities (FLASH/UAC), Benin. 